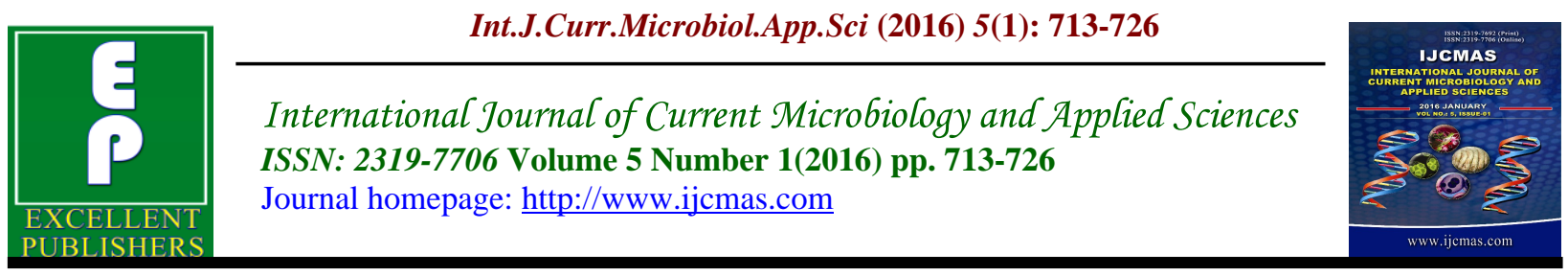

Review Article

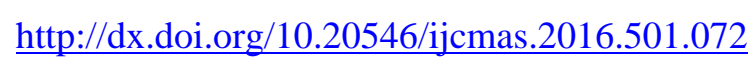

\title{
Nanotechnology in Wastewater Treatment; Influence of Nanomaterials on Microbial Systems
}

\author{
Mahmoud M. Berekaa* \\ Environmental Health Department, College of Applied Medical Sciences, \\ University of Dammam, Dammam 31441, Saudi Arabia \\ *Corresponding author
}

\begin{abstract}
A B S T R A C T
Keywords

Nanoparticles,

Nanosensors,

Nanocatalyst,

Nanocomposite

membranes,

Disinfection,

Article Info

Accepted:

25 December 2015

Available Online:

10 January 2016

During the last few decades there is growing interest for the use of nanoparticles in water and wastewater treatment technology, due to their distinctive physiochemical characteristics. This review outlines the conceivable opportunities regarding the interaction of nanoparticles with the biological systems during water and wastewater treatment processes. An overview on the recent advances in application of nanoparticles in biofouling prevention and disinfection is provided. Recent advances in nanoscience allow for development of nanosensors for biomonitoring and diagnostic purposes. Due to remarkable use of nanoparticles, wastewater treatment plants received considerable amount of NPs such as $\mathrm{TiO}_{2}, \mathrm{ZnO}$, $\mathrm{N}_{2} \mathrm{O}, \mathrm{AgO}, \mathrm{CuO}, \mathrm{SiO}_{2}, \mathrm{Al}_{2} \mathrm{O}_{3}$ and $\mathrm{CeO}_{2}$. Toxic effects of nanoparticles on structural and physiological activity of various microbial communities including; nitrification, denitrification and phosphorus removal processes are critically reviewed.
\end{abstract}

\section{Introduction}

Water is the most vital substance in our life. Reliable and sustainable access to clean, safe and affordable water is considered to be one of the most essentials for human being. Approximately, one-sixth of the world's population suffers from access to clean drinking water (WHO, 2004). Nowadays, overpopulation, limited water resources, pollution and lack of water sustainability are considered as the most common difficulties facing human needs.
Therefore, an urgent need is required to develop an innovative technology to provide clean and affordable water to meet human needs.

Over the last few decades, nanotechnology is emerging as a rapidly growing sector of a "knowledge-based economy" due to unique physiochemical properties of nanomaterial. This technology gained a tremendous impetus due to its capability of 
reformulating the particle of metals into new nano-sized form, with dimension less than $100 \mathrm{~nm}$ in size. Hence, it is used in manufacture of a wide range of products and in wastewater treatment (Bora and Dutta, 2014; Wang et al., 2014; Qu et al., 2013; Yang et al., 2013; Yang et al., 2012; Guzman et al., 2006). Due to remarkable use of nanoparticles, wastewater treatment plants received considerable amount of nanoparticles such as $\mathrm{TiO}_{2}, \mathrm{ZnO}, \mathrm{N}_{2} \mathrm{O}, \mathrm{AgO}$, $\mathrm{CuO}, \mathrm{SiO}_{2}, \mathrm{Al}_{2} \mathrm{O}_{3}$ and $\mathrm{CeO}_{2}$, with potential risk to human and environment (Brar et al., 2010; Klaine et al., 2008; Nel et al., 2006 ).

Recently, implementation of nanotechnology in wastewater treatment enabled high performance, reasonable water and wastewater treatment solutions that less relies on large infrastructures $(\mathrm{Qu}$ et al., 2013). Wide range of nanomaterials tested regarding resistance of biofouling, elimination of toxic metals, organic and inorganic pollutants, pathogen detection as well as disinfection (Amin et al., 2014; Prachi et al., 2013; Qu et al., 2013; Richards et al., 2012; Tiwari et al., 2008). From economic point of view, nanotechnology allow for utilization of the most challenging water resources and energy conservation. Unfortunately, costs of this new technology should be properly managed due to competition with traditional wastewater treatment technologies (Crane et al., 2012).

This review outlines the conceivable opportunities regarding applications of nanoparticles in biofouling prevention, disinfection and as sensors for pathogen detection (Table 1). An overview on recent advances to discuss the major interaction of nanoparticles with biological systems in water and wastewater treatment is provided. Toxicity effect of nanoparticles on structural and physiological activity of microbial communities as well as nitrification, denitrification and phosphorus removal is critically reviewed.

\section{Biofouling Resistance}

\section{Nanocomposite Membranes}

Among major challenges of membrane technology in wastewater treatment is the membrane biofouling and virus penetration (Barhate and Ramakrishna, 2007). Recently, incorporation of functional nanomaterials into ultrafilteration membrane systems allow for improvement of membrane properties especially; mechanical and thermal stability, membrane permeability and fouling resistance through increasing membrane hydrophobicity. Nanoparticles used for this purposes are; $\mathrm{Al}_{2} \mathrm{O}_{3}, \mathrm{TiO}_{2}$, zeolite, nano-Ag and CNTs, bi-metallic nanoparticles and $\mathrm{TiO}_{2}$ (Bottino et al., 2001; Ebert et al., 2004; Bae and Tak, 2005; Maximous et al., 2010; Pendergast et al., 2010).

For example; incorporation of silver nanoparticles into polymeric membranes led to inhibition of bacterial growth, biofilm formation and inactivated viruses (Zodrow et al., 2009; De Gusseme et al., 2011; Mauter et al., 2011). Applications of carbon nanotubes CNTs in inactivation of bacteria was reported (Brady-Estevez et al., 2008). Ahmed et al. (2012) recorded that more than $90 \%$ of bacteria inactivated by using polyvinyl-N-carbazole-SWNT nanocomposite at $3 \mathrm{wt} \%$ of SWNT. In addition, hydrophobicity and permeability of the polysulfone membranes were increased by addition of oxidized MWNT in a very low amount (Choi et al., 2006b). On the other hand, membranes incorporated with photocatalytic nanoparticles $\quad\left(\mathrm{TiO}_{2}\right.$ nanoparticles) were developed to degrade some contaminants (Choi et al., 2006a). Interestingly, nanocatalysts based on semiconductor materials, zero-valence metal and bimetallic nanoparticles used in degradation of many environmental 
contaminants such as PCBs (polychlorinated biphenyls), azo-dyes, halogenated aliphatic, organochlorine pesticides, halogenated herbicides, and nitro aromatics (Xin et al., 2011; Wu and Ritchie, 2008; Wu et al., 2005).

\section{Thin Film Nanocomposite Membranes (TFN)}

Breakthrough in efficiency of thin film nanocomposite membranes (TFN) achieved by the use of nano-zeolites for enhancement of membrane permeability. Jeong et al. (2007) reported the increase of salt rejection up to $80 \%$ over TFC was with salt rejection of $93.9 \%$. Furthermore, Lind et al. (2010) reported that TFC incorporated with $250 \mathrm{~nm}$ nano-zeolites $\quad(0.2 \% \mathrm{wt}) \quad$ enhanced permeability and increased salt rejection up to $80 \%$ than commercial reverse osmosis membranes. Interestingly, nano-zeolites used as carriers for antimicrobial agents such as Agp, which incorporate antifouling property to the membrane (Lind et al., 2009).

Moreover, Lee et al. (2008) revealed that incorporation of nano- $\mathrm{TiO}_{2}$ into the TFC membrane slightly increased rejection process. Indeed, reduction of biological contaminants, biological fouling and inactivation of microorganisms achieved by photocatalyic activity of $\mathrm{TiO}_{2}$ upon UV irradiation(Chong et al., 2010). However, membrane material may encounter negative effects due to long-term exposure (Chin et al., 2006).Carbon nanotubes CNTs applied in TFN membranes due to their antimicrobial activities (Tiraferri et al., 2011).Moreover, $\mathrm{TiO}_{2}$ nanotubes showed great efficiency in decomposition of organic compounds (Macak et al., 2007).

\section{Disinfection}

It is well recognized that traditional water disinfection methods might lead to adverse effect. Chlorination and ozone may lead to generation of toxic or mutagenic byproducts, hence increase risk of cancer (Monarca et al. 2004). On the other hand, germicidal activity of ultraviolet (UV) irradiation depends on the total suspended solids that may reduce the activity (Chang et al. 1985). Therefore, progressive increase in research focuses on development of a novel water disinfection method to overcome limitations encountered by other methods (Qu et al., 2013). Variety of nanoparticles, e.g.; Ag, nano- $\mathrm{ZnO}$, nano- $\mathrm{TiO}_{2}$ and carbon nanotubes potentially used in disinfection of water and wastewater (Li et al. 2008; Vahabi et al. 2011; Baruah et al.,2012). Elmi et al. (2014) synthesized $\mathrm{ZnO}$ nanoparticles by mechano-chemical and solgel methods. The nanoparticles were successfully used as antimicrobial agent in wastewater treatment, preferably with UV disinfection to improve water quality.

\section{Antimicrobial Activity}

Antimicrobial activity of many nano-sized metal ions (nanoparticles) allows for design of nanocatalyts such as; AgCCA catalyst, $\mathrm{N}$-doped $\mathrm{TiO}_{2}$ and $\mathrm{ZrO}_{2}$. The high efficiency of nanoparticles led to removal of microbial contaminants from wastewater (Shalini et al., 2012). $\mathrm{TiO}_{2}$-AGS composite is efficient in remediation of toxic $\mathrm{Cr}$ (VI) ions from wastewater. Indeed, enhanced biodegradation of halogenated organic compounds; based on specific interaction between halogens and $\mathrm{Pd}$ nanoparticles was reported (Zhang et al., 2012). Interestingly, the ferromagnetic properties of nanocatalysts are highly beneficial in their recycle and reuse. Also, silver-based nanocatalyst was efficiently used for degradation of organic dyes (Wu et al., 2010). Indeed, photacatalytic activity of $\mathrm{Pd}$ incorporated $\mathrm{ZnO}$ nanparticles allows for 
removal of $E$. coli from wastewater (Khalil et al., 2011). In another approach, palladium nanoparticles (PdNPs) used as catalyst for in situ bioremediation and reduction of highly toxic $\mathrm{Cr}$ (VI) to less toxic Cr (III) ions (Omole et al., 2009). Interestingly, the reactivity of catalyst can be enhanced by combination with nanosorbents i.e. combining sorption and degradation of contaminants in wastewater.

The possible usage of nanomaterials including; nano-Ag, nano- $\mathrm{ZnO}$, nano- $\mathrm{TiO}_{2}$, nano- $\mathrm{Ce}_{2} \mathrm{O}_{4}$, and CNTs in disinfection and pathogens control, with clear explanation for the mechanism, limitations and application in wastewater treatment, has previously revised by Li et al., (2008) and updated by $\mathrm{Qu}$ et al., (2013). Evidently, the drastic effect of nanoparticles on microbial cells ranged from potential damage to proteins and cell membrane, suppression of DNA replication, generation of toxic reactive oxygen species and inactivation of enzymes (Wang et al., 2014; Vecitis et al., 2010, Xiu et al., 2011, Feng et al., 2000, Liau et al., 1997).

The crucial role of nanomaterials during wastewater treatment relays on their antimicrobial activity during disinfection, membrane biofouling control, as well as control of biofilm formation on various surfaces. Peter-Varbanets et al., 2009 reported the possible use of Agnanoparticles for disinfection and against waterborne pathogens by incorporation into ceramic microfilters. Indeed, commercial devices based on Ag-nanoparticles are already available e.g. MARATHON_ and Aquapure_ systems. Indeed, novel antimicrobial CNT filter designed for removal of bacteria and viruses (BradyEstevez et al., 2010). The retained microbes are inactivated by CNTs within hours. However, application of small voltage can drastically decrease the time to few seconds
(Rahaman et al., 2012). Advantageous use of nanomaterials as antimicrobial agent allows for their incorporated into storage tanks and distribution pipes surfaces to prevent microbial contamination, biofilm formation and corrosion ( $\mathrm{Qu}$ et al., 2013). Recently, antimicrobial peptides synthesized as nanoparticles through self-immobilization mediated by biomineralization reactions to increase stability and protection (Eby et al., 2008). Brogden (2005) mentioned that the biocidal effect of peptide nanoparticle is due to interaction between the nanoparticles with the bacterial cell membrane.

\section{Sensing and Monitoring}

Due to extreme importance of water and wastewater monitoring specially regarding detection of pathogenic microorganisms, there is crucial need for innovative sensors. These sensors should meet high quality standards including; high sensitivity, selectivity, reliability, ease-of-use and quick response in contaminant detection. Advances in nanotechnology are having a significant impact on the field of diagnostics and biomolecular detection (Table 1) (Fortina et al., 2005). Interestingly, new synthesis and fabrication of nanomolecules allows for possible tailor of their binding affinities for various biomolecules through surface modification and engineering (Rosi and Mirkin, 2005).

\section{Pathogen Detection}

In the meantime, most of conventional indicator systems are insensitive enough regarding diagnosis of many human pathogens in drinking water (Theron et al., 2010). However, the development of pathogen sensors could be a possible solution. Advances in sensors technology based on nanomaterial focused on the development of sensitive and fast responsive recognition elements and signal transducer, 
due to their unique physiochemical characteristics (Vikesland and Wigginton, 2010). Recently, nanosensors developed for detection of whole cells and biomolecules (Theron et al., 2010, Vikesland and Wigginton, 2010). Nanomaterials such as magnetic nanoparticles, CNTs, noble metals, Quantum dots (QDs) and dye-doped nanoparticles used in pathogen detection(Yan et al., 2007, Sukhanova et al.,2004; Petryayeva and Krull, 2011; Jain et al., 2006).

Nowadays, CNTs gain tremendous attention in design of electrodes due to ease electrochemical detection through promotion of electron transfer, interactions and high adsorption capacity (McCreery, 2008, Collins et al., 2000). CNTs applied as a single nanotube electrode, or incorporated into electrodes via random or aligned coating or used in nanoscale (Yang et al., 2010, Heller et al., 2008). Unfortunately, heterogeneity and nonspecific binding are the major challenges for application of CNTs nanosensors in water and wastewater treatment.

Table.1 Microbiological Applications of Nanotechnology in Wastewater Treatment

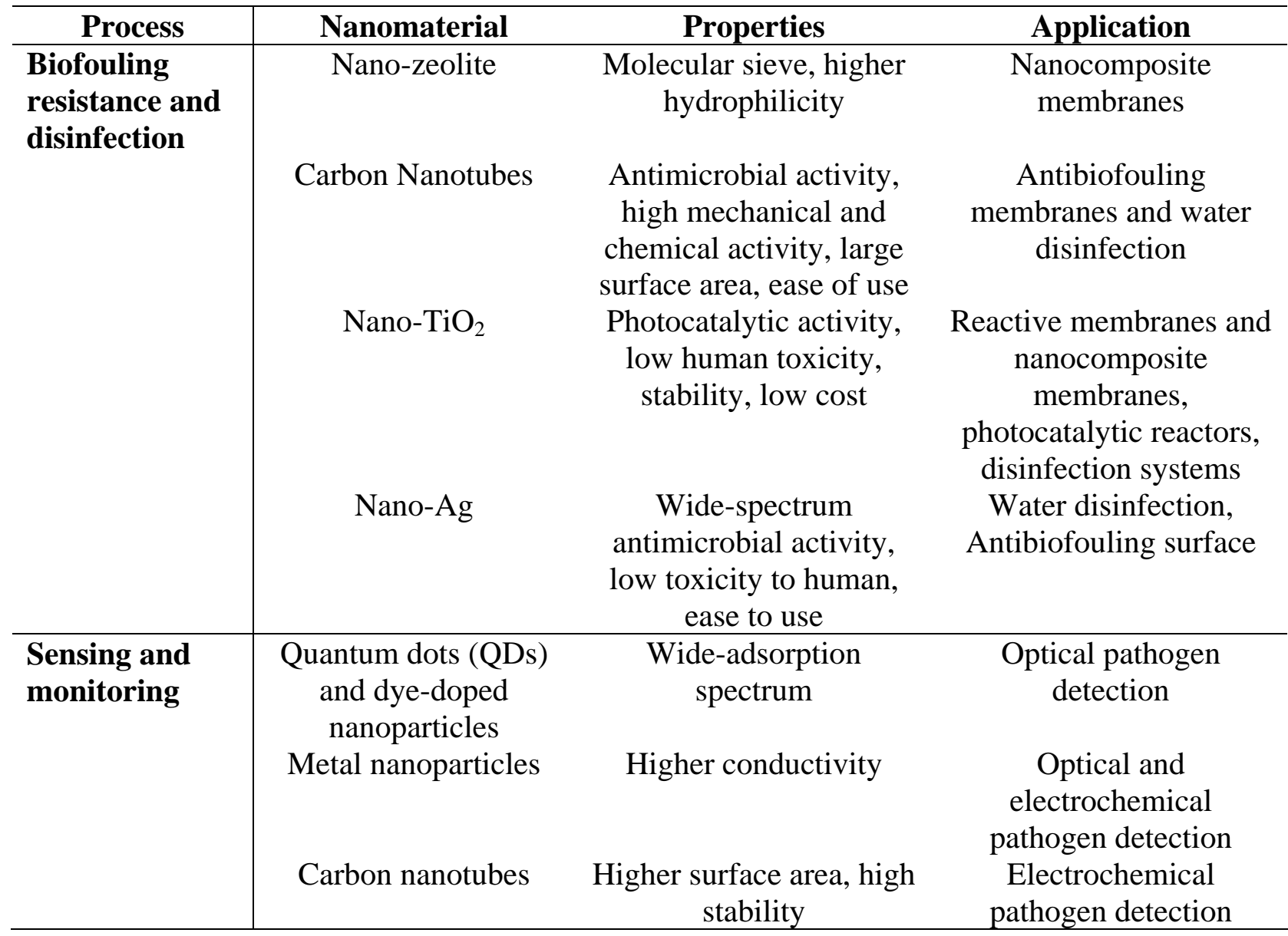

Adopted from Qu et al., 2013 and Cloete et al., 2010

\section{Toxicity}

Due to tremendous use of nanoparticles, wastewater treatment plants (WWTPs) based on activated sludge treatment process 
received considerable amount of NPs as $\mathrm{TiO}_{2}, \mathrm{ZnO}, \mathrm{N}_{2} \mathrm{OAgO}, \mathrm{CuO}, \mathrm{SiO}_{2}, \mathrm{Al}_{2} \mathrm{O}_{3}$ and $\mathrm{CeO}_{2}$ (Chen et al., 2012a, 2012b; Choi and $\mathrm{Hu}, 2008$; Hou et al., 2012; Zheng et al., 2012, 2011a,b). Possible removal of NPs from activated sludge in wastewater treatment via adsorption, aggregation and settling processes was reported (Hou et al., 2012; Stark et al., 2008). For example, tremendous application of nanoparticles (e.g. AgNPs) led to continuous release to environment and discharge to wastewater treatment facilities (Benn and Westerhoff, 2008; Blaser et al., 2008). It is estimated that the concentrations of AgNPs in effluent and sludge samples of WWTPs are 0.021 $\mathrm{mg} / \mathrm{L}$ and $1.55 \mathrm{mg} / \mathrm{kg}$, respectively (Gottschalk et al., 2009). The predicted effluent total silver concentrations in wastewater treatment range from 2 to 18 $\mathrm{mg} / \mathrm{L}$ (Blaser et al., 2008). This value can be increased to $105 \mathrm{mg} / \mathrm{L}$ in case of industrial discharges (Shafer et al., 2009). Discharge may leads to decrease in the effectiveness of biological wastewater treatment process due to toxicity measures. Recently, Kiser et al. (2009) reported that most of NPs released into the environment retained in biological wastewater treatment systems.

Furthermore, widespread application of silver nanoparticles as antimicrobial agent might help in contamination of aquatic ecosystems. Das et al. (2012) recorded that bacterial growth and extracellular alkaline phosphatase were significantly reduced in nine Ag NP-exposed samples after 1 hour. After $48 \mathrm{~h}$, bacterial growth was recovered by 40 to $250 \%$ at low AgNP concentrations. In contrast, addition of $\mathrm{AgNO}_{3}$ (from 0.01 to $2 \mathrm{mg} \mathrm{Ag} / \mathrm{L})$ led to complete inhibition of bacterial growth over the $48 \mathrm{~h}$ exposure.

Crucial effect of silica-based nanoparticles (e.g. $\mathrm{SiO}_{2}$ NPs) on biological removal of nitrogen and phosphorus was discussed (Zheng et al., 2012, 2011a,b). As revealed by DGGE and qPCR assays, the structure of microbial community was significantly changed. Denitrifying enzyme activities was decreased due to chronic exposure of activated sludge to $50 \mathrm{mg} / \mathrm{L}$ of $\mathrm{SiO}_{2} \mathrm{NPs}$ nanoparticles, while phosphorus removal was not affected (Zheng et al., 2012).

Chen et al. (2014) indicated that the long term exposure of sludge fermentation system to higher concentration of $\mathrm{TiO}_{2} \mathrm{NPs}$, exert marginal influence on bacteria and methanogenic archaea, probably due to exopolymers. However, the microbial activities as well as methane production were not affected. In another approach, no significant difference in activated sludge microbial community was detected after long term exposure of membrane bioreactor (MBR) process to higher concentration of silver nanoparticles $(0.010 \mathrm{mg} \mathrm{Ag} / \mathrm{L}$ ) (Zhang et al., 2014). Although, nitrifying bacterial community as well as membrane fouling rate were not changed whereas, the extracellular polymeric substances (EPS) significantly increased after each nanosilver dosing. Zhang el al. (2014) suggested that microbial activities in activated sludge help to reduce nanosilver particles toxicity through adsorption or precipitation.

Analysis of microbial community in activated sludge after exposure to $1 \mathrm{mg} / \mathrm{L}$ AgNPs was monitored by $16 \mathrm{~S}$ rRNA gene analysis through DGGE (Sun et al., 2013). No change in heterotrophic plate count was detected; however, specific microbial communities in the intact activated sludge flocs were highly sensitive to Ag NPs. This effect depends on the physical structure of the flocs, spatial distribution of microorganisms, and the community structures in the activated sludge flocs (Sun et al., 2013).

Musee et al. (2011) revealed that the effect of engineered nanoparticles ENPs on 
microbial community of WWTPs depends on several factors e.g. type, size, surface area, $\mathrm{pH}$, temperature, composition of organic matter. To depict the potential risk of nanoparticles discharged into the environment, the impact of Ag NPs on the growth of $P$. aeruginosa in presence of humic acid material was investigated (Fabrega et al., 2009). It was recorded that the humic material caused a partial disaggregation of Ag NP aggregates by nanoscale film formation. Moreover, dissolved Ag reduced bacterial growth at 19 $\mu \mathrm{M}$ under different environmental conditions.

The short- as well as the long-term toxic effect of alumina nanoparticles $\left(\mathrm{Al}_{2} \mathrm{O}_{3} \mathrm{NP}\right)$ on wastewater bacterial community (especially for nitrogen and phosphorus removal) was investigated by Chen et al. (2012a). These nanoparticles adsorbed on the activated sludge flocs, without affecting its integrity and viability. However, nitrification, denitrification and $\mathrm{P}$ removal were slightly influenced during short-term exposure to 1 and $50 \mathrm{mg} / \mathrm{L}$ of $\mathrm{Al}_{2} \mathrm{O}_{3} \mathrm{NPs}$. Nevertheless, long-term exposureto $50 \mathrm{mg} / \mathrm{L}$ $\mathrm{Al}_{2} \mathrm{O}_{3}$ NPs decrease the denitrifying enzyme activities or denitrification process and total nitrogen removal from $80.4 \%$ to $62.5 \%$, although $\mathrm{P}$ removal and PHAs as well as glycogen were not affected.

For actual assessment of nanoparticles toxicity, a simulation study was carried out by Chen et al. (2014b). In this study, $\mathrm{Cu}$ NPs were added to influent before anaerobic treatment of wastewater for production of volatile fatty acids. Interestingly, no significant effect was documented. However, addition of $\mathrm{Cu}$ NPs directly to the sludge reactor reduced VFA production. Furthermore, incorporation of $\mathrm{Cu}$ NPs into wastewater treatment system improved sludge solubilization due to reduced sludge particle size as well as the link between sludge and microorganisms. Dramatic decrease in hydrolysis, acidification of the sludge and VFA production was recorded due to direct addition of NPs to the fermentation system (Chen et al., 2014b).

\section{Conclusion and Perspectives}

Although water plays a crucial role in every facet of human activity, it is becoming an increasingly scarce resource in many parts of the world. It is recognized that nanotechnology and their applications play an important role in resolving issues relating to water shortage and water quality. Owing to larger surface areas and size-dependent catalytic properties of nanomaterials, considerable efforts are being done to explore their application especially in wastewater treatment. Moreover, nanomaterials can be ligand to different chemical groups to increase affinity, recyclability, high capacity and selectivity. Although much attention focused on the development and potential benefits of nanomaterials in water and wastewater treatment processes, concerns raised regarding their potential human an environmental toxicity. Generally, a common framework for risk research, risk assessment, and risk management are still lacking. Nevertheless, development of novel nanomaterials will play a key role in ensuring sufficient and good quality water to meet the ever-increasing demand for drinking water. On the other hand, the high availability, low cost and high wide antimicrobial activity of many nanoparticles makes them attractive in water purification. Indeed, due to emergency of many waterborne diseases and limited safe water resources, there is a great demand for improvement of water filtration system. Nanofibers and nanobiocides can be useful solution to ensure safe and easy access 
drinking water. Due to recent advances in nanotechnology, next generation of diagnostic methods for pathogen detection is developing. However, some technical and practical problems need to be resolved before potential realization. This includes tight control over synthesis and functionalization. Besides, sample processing, detection of multiple agents in a single sample, as well as improving sensitivity and selectivity of the assays for significant application to complex environmental samples is highly recommended.

\section{References}

Ahmed, F., Santos, C.M., Vergara, R., Tria, M.C.R., Advincula, R., and Rodrigues, D.F. 2012.Antimicrobial applications of electroactive PVK-SWNT nanocomposites. Environmental Science and Technology 46(3), 18041810.

Amin, M. T., Alazba, A. A., and Manzoor, U. 2014. A Review of Removal of Pollutants from Water/Wastewater Using Different Types of Nanomaterials. Advances in Materials Science and Engineering, Article ID 825910, 1-24.

Bae, T.H., and Tak, T.M. 2005. Effect of $\mathrm{TiO}_{2}$ nanoparticles on fouling mitigation of ultrafiltration membranes for activated sludge filtration. Journal of Membrane Science 249(1-2), 1-8.

Barhate, R. S. and Ramakrishna, S. 2007. Nanofiberous filtering media: filtration problems and solutions from tiny materials. Journal of Membrane Science 296: 1-8.

Baruah, S. K., Pal, S. andDutta, J. 2012. Nanostructured zinc oxide for water treatment. Nanoscience Nanotechnology-Asia 2, 90-102.

Benn, T.M., and Westerhoff, P. 2008.
Nanoparticle silver released into water from commercially available sock fabrics. Environmental Science and Technology 42(11): 4133- 4139.

Blaser, S.A., Scheringer, M., MacLeod, M., and Hungerbuhler, K. 2008. Estimation of cumulative aquatic exposure and risk due to silver: contribution of nano-functionalized plastics and textiles. Science Total Environment 390(2): 396-409.

Bora, T and Dutta, J., 2014.Applications of nanotechnology in wastewater treatment--a review.J NanosciNanotechnol., 14(1):613-26.

Borgden, K. A. 2005, Antimicrobial peptides: pore formers or metabolic inhibitors in bacteria? Nature Review in Microbiology 3: 238-250.

Bottino, A., Capannelli, G., D'Asti, V., and Piaggio, P. 2001. Preparation and properties of novel organic-inorganic porous membranes. Separation and Purification Technology 22-23(1-3): 269-275.

Brady-Estevez, A.S., Kang, S., and Elimelech, M. 2008.A singlewalledcarbon-nanotube filter for removal of viral and bacterial pathogens. Small 4 (4): 481-484.

Brady-Estevez, A.S., Schnoor, M.H., Kang, S., and Elimelech, M. 2010. SWNTMWNT hybrid filter attains high viral removal and bacterial inactivation. Langmuir 26(24): 19153-19158.

Brar, S.K., Verma, M., Tyagi, R.D., and Surampalli, R.Y. 2010. Engineered nanoparticles in wastewater and wastewater sludge e evidence and impacts. Waste Manag. 30(3): 504520.

Brogden, K. A. 2005. Antimicrobial peptides: pore formers or metabolic inhibitors in bacteria. Nature Review in Microbiology 3: 238-250.

Chang, J. C., Ossoff, S. F., Lobe, D. C., 
Dorfman, M. H., Dumais, C. M., Qualls, R. G., and Johnson, J. D. 1985. UV inactivation of pathogenic and indicator microorganisms. Appliedand Environmental Microbiology 49: 1361-1365.

Chen, H., Chen, Y., Zheng, X., Li, X., and Luo, J. 2014a. How does the entering of copper nanoparticles into biological wastewater treatment system affect sludge treatment for VFA production. Water Research 63: 125-134.

Chen, Y., Mu H., and Zheng X. 2014b. Chronic Response ofWaste Activated Sludge Fermentation to Titanium Dioxide Nanoparticles. Chinese Journal of Chemical Engineering 22: 1162-1167.

Chen, Y., Su, Y., Zheng, X., Chen H., and Yang, H. 2012a. Alumina nanoparticles-induced effects on wastewater nitrogen and phosphorus removal after short-term and long-term exposure.water research 46: 43794386.

Chen, Y., Wang, D., Zhu, X., Zheng, X., and Feng, L. 2012b.Long-term effects of copper nanoparticles on wastewater biological nutrient removal and $\mathrm{N}_{2} \mathrm{O}$ generation in the activated sludge process. Environmental Science and Technology 46(22): 12452-12458.

Chin, S.S., Chiang, K., and Fane, A.G., 2006. The stability of polymeric membranes in a $\mathrm{TiO}_{2}$ photocatalysis process. Journal of Membrane Science 275(1-2): 202-211.

Choi, H., Stathatos, E., and Dionysiou, D.D. 2006a.Sol-gel preparation of mesoporousphotocatalytic $\mathrm{TiO}_{2}$ films and $\mathrm{TiO}_{2} / \mathrm{Al}_{2} \mathrm{O}_{3}$ composite membranes for environmental applications.Applied Catalysis B-Environmental 63(1-2): 60-67.

Choi, J.H., Jegal, J., and Kim, W.N. $2006 b$. Fabrication and characterization of multi-walled carbon nanotubes/polymer blend membranes. Journal of Membrane Science 284(12): 406-415.

Choi, O., and Hu, Z.Q. 2008. Size dependent and reactive oxygen species related nanosilver toxicity to nitrifying bacteria. Environmental Science and Technology 42(12): 4583-4588.

Chong, M.N., Jin, B., Chow, C.W.K., and Saint, C. 2010. Recent developments in photocatalytic water treatment technology: a review. Water Research 44(10): 2997-3027.

Cloete, T.E., de Kwaadsteniet, M., Botes, M., and Lopez-Romero, J. M. 2010.Nanotechnology in Water Treatment Applications.Caister Academic Press $1^{\text {St }}$ edn. Norfolk, UK.

Collins, P.G., Bradley, K., Ishigami, M., and Zettl, A., 2000.Extreme oxygen sensitivity of electronic properties of carbon nanotubes. Science 287(5459): 1801-1804.

Crane, R. A., and Scott T. B. 2012.Nanoscale zero-valent iron: Future prospects for an emerging water treatment technology. Journal of Hazardous Materials 211-212: 112125.

Das, P., Xenopoulos, M. A., Williams, C. J., Hoque, M. E., and Metcalfe, C. D. 2012. Effects of Silver Nanoparticles on Bacterial Activity in Natural Waters. Environmental Toxicology and Chemistry 31(1): 122-130.

De Gusseme, B., Hennebel, T., Christiaens, E., Saveyn, H., Verbeken, K., Fitts, J.P., Boon, N., and Verstraete, W. 2011.Virus disinfection in water by biogenic silver immobilized in polyvinylidene fluoride membranes. Water Research 45(4): 1856-1864.

Ebert, K., Fritsch, D., Koll, J., and Tjahjawiguna, C. 2004. Influence of inorganic fillers on the compaction 
behaviour of porous polymer based membranes. Journal of Membrane Science 233(1-2): 71-78.

Eby, D. M., Farrington, K. E., and Johnson, G. R. 2008. Synthesis of bioinorganic antimicrobial peptide nanoparticles with potential therapeutic properties. Biomacromolecules 9: 2487-2494.

Elmi, F., Alinezhad, H., Moulana, Z., Salehian, F., Tavakkoli, S. M., Asgharpour, F., Fallah, H., and Elmi, M. M. 2014.The use of antibacterial activity of $\mathrm{ZnO}$ nanoparticles in the treatment of municipal wastewater. Water Science and Technology 70(5): 763-770.

Fabrega, J., Fawcett, S. R., Renshaw, J. C., and Lead, J. R. 2009. Silver nanoparticle impact on bacterial growth: effect of $\mathrm{pH}$, concentration, and organic matter. Environmental Science and technology 43: 72857290.

Feng, Q.L., Wu, J., Chen, G.Q., Cui, F.Z., Kim, T.N., and Kim, J.O. 2000.A mechanistic study of the antibacterial effect of silver ions on Escherichia coli and Staphylococcus aureus. Journal of Biomedical Materials Research 52(4): 662-668.

Fortina, P., Kricka, L. J., Surrey, S., and Gordzinki, $\quad$ P. 2005. Nanobiotechnology: The promise and reality of new approaches to molecular recognition. Trends in Biotechnology 23: 168-173.

Gottschalk, F., Sonderer, T., Scholz, R.W., and Nowack, B. 2009.Modeled environmental concentrations of engineered nanomaterials ( $\mathrm{TiO} 2, \mathrm{ZnO}$, $\mathrm{Ag}, \mathrm{CNT}$, fullerenes) for different regions. Environmental Science and Technology 43(24): 9216-9222.

Guzman, K.A.D., Taylor, M.R., and Banfield, J.F. 2006. Environmental risks of nanotechnology: National
Nanotechnology initiative funding, 2000-2004. Environmental Science and Technology 40(5): 1401-1407.

Heller, I., Janssens, A.M., Mannik, J., Minot, E.D., Lemay, S.G., and Dekker, C. 2008.Identifying the mechanism of biosensing with carbon nanotube transistors. Nano Letters 8(2): 591595.

Hou, L.L., Li, K.Y., Ding, Y.Z., Li, Y., Chen, J., Wu, X.L., and Li, X.Q. 2012. Removal of silver nanoparticles in simulated wastewater treatment processes and its impact on COD and $\mathrm{NH}_{4}$ reduction. Chemosphere 87(3): 248-252.

Jain, P.K., Lee, K.S., El-Sayed, I.H., and ElSayed, M.A. 2006. Calculated absorption and scattering properties of gold nanoparticles of different size, shape, and composition: applications in biological imaging and biomedicine. Journal of Physical Chemistry B 110(14): 7238-7248.

Jeong, B.H., Hoek, E.M.V., Yan, Y.S., Subramani, A., Huang, X.F., Hurwitz, G., Ghosh, A.K., and Jawor, A. 2007. Interfacial polymerization of thin film nanocomposites: a new concept for reverse osmosis membranes. Journal of Membrane Science 294(1-2): 1-7.

Khalil, A., Gondal, M.A., and Dastageer, M.A. 2011. Augmented photocatalytic activity of palladium incorporated $\mathrm{ZnO}$ nanoparticles in the disinfection of Escherichia coli microorganism from water. Applied Catalysis A: General 402(1-2): 162-167.

Kiser, M. A., Westerhoff, P., Benn, T., Wang, Y., Perez-Rivera, J., and Hristovski, K. 2009.Titanium nanomaterial removal and release from wastewater treatment plants. Environmental Science and Technology 43(17): 6757-6763

Klaine, S.J., Alvarez, P.J.J., Batley, G.E., 
Fernandes, T.F., Handy, R.D., Lyon, D.Y., Mahendra, S., McLaughlin, M.J., and Lead, J.R. 2008. Nanomaterials in the environment: behavior, fate, bioavailability, and effects. Environmental Toxicologyand Chemistry 27(9): 1825-1851.

Lee, H.S., Im, S.J., Kim, J.H., Kim, H.J., Kim, J.P., and Min, B.R. 2008.Polyamide thin-film nanofiltration membranes containing $\mathrm{TiO}_{2}$ nanoparticles. Desalination 219(13): 48-56.

Li, Q., Mahendra, S., Lyon, D. Y., Brunet, L., Liga, M. V., Li, D. and Alvarez, P. J. 2008.Antimicrobial nanomaterials for water disinfection and microbial control: Potential applications and implications. Water Resouces 42: 4591-4602.

Liau, S.Y., Read, D.C., Pugh, W.J., Furr, J.R., and Russell, A.D. 1997. Interaction of silver nitrate with readily identifiable groups: relationship to the antibacterial action of silver ions. Letters in Applied Microbiology 25(4): 279-283.

Lind, M.L., Jeong, B.H., Subramani, A., Huang, X.F., and Hoek, E.M. V. 2009.Effect of mobile cation on zeolite-polyamide thin film nanocomposite membranes. Journal of Materials Research 24(5): 1624-1631.

Lind, M.L., Suk, D.E., Nguyen, T.V., and Hoek, E.M.V. 2010.Tailoring the structure of thin film nanocomposite membranes to achieve seawater RD membrane performance. Environmental Science and Technology 44(21): 8230-8235.

Macak, J.M., Zlamal, M., Krysa, J., and Schmuki, P. 2007. Selforganized $\mathrm{TiO}_{2}$ nanotube layers as highly efficient photocatalysts. Small 3 (2): 300-304.

Mauter, M.S., Wang, Y., Okemgbo, K.C., Osuji, C.O., Giannelis, E.P., and
Elimelech, M. 2011. Antifouling ultrafiltration membranes via postfabrication grafting of biocidalnanomaterials. ACS Applied Materials and Interfaces 3(8): 28612868.

Maximous, N., Nakhla, G., Wong, K., and Wan, W. 2010. Optimization of $\mathrm{Al}(2) \mathrm{O}(3) / \mathrm{PES}$ membranes for wastewater filtration. Separation and Purification Technology 73(2): 294301.

McCreery, R.L. 2008.Advanced carbon electrode materials for molecular electrochemistry. Chemical Reviews 108(7): 2646-2687.

Monarca, S., Zani, C., Richardson, S. D., Thruston Jr., A. D., Moretti, M., Feretti, D.,andVillarini, M. 2004. A new approach to evaluating the toxicity and genotoxicity of disinfected drinking water. Water Resources 38: 3809-3819.

Musee, N., Thwalaa, M., and Nota, N. 2011. The antibacterial effects of engineered nanomaterials: implications for wastewater treatment plants. Journal of Environmental Monitoring 5(13): 1164-1183.

Nel, A., Xia, T., Madler, L., and Li N. 2006.Toxic potential of materials at the nanolevel. Science 311 (5761): 622-627.

Omole, M. A., Owino I., K., andOmowunmi A., Sadik, 2009. Nanostructured Materials for Improving Water Quality: Potentials and Risks. In: Nanotechnology Applications for Clean Water (Eds.) N. Savage, M.Diallo, J. Duncan, A. Street and R. Sustich. William Andrew, Norwich NY.Pp. 233-247.

Pendergast, M.T.M., Nygaard, J.M., Ghosh, A.K., and Hoek, E.M. V. 2010. Using nanocomposite materials technology to understand and control reverse 
osmosis membranecompaction.

Desalination 261(3): 255-263.

Peter-Varbanets, M., Zurbrugg, C., Swartz, C., and Pronk, W. 2009.Decentralized systems for potable water and the potential of membrane technology. Water Research 43(2): 245-265.

Petryayeva, E., and Krull, U. J. 2011. Localized surface plasmon resonance: nanostructures, bioassays and biosensing e a review. AnalyticaChimicaActa 706(1): 8-24.

Prachi, Gautam P., Madathil D., and Nair A. N. B. 2013. Nanotechnology in Waste Water Treatment: A Review. 5(5): 2303-2308.

$\mathrm{Qu}$, X., Alvarez P. J. J., and Li Q. 2013.Applications of nanotechnology in water and wastewater treatment. Water Research 47: 3931-3946.

Rahaman, M.S., Vecitis, C.D., and Elimelech, M. 2012. Electrochemical carbon-nanotube filters performance toward virus removal and inactivation in the presence of natural organic matter. Environmental Science and Technology 46(3): 1556-1564.

Richards, H. L., Baker, P. G. L., and Iwuoha, E. 2012. Metal Nanoparticle Modified Polysulfone Membranes for Use in Wastewater Treatment: A Critical Review. Journal of Surface Engineered Materials and Advanced Technology 2: 183-193.

Rosi, N. L., and Mirkin, C. A.2005.Nanostructures in biodiagnostics. Chemical Review 105: 1547-1562.

Shafer, M.M., Overdier, J.T., and Armstong, D. E. 2009.Removal, partitioning, and fate of silver and other metals in wastewater treatment plants and effluent-receiving streams. Environmental Toxicologyand Chemistry 17(4): 630-641.

Shalini, C. A., Pragnesh, N., Dave, A., and
Shah, N. K. 2012.Applications of nano-catalyst in new era. Journal of Saudi Chemical Society 16(3): 307325.

Stark, W.J., Limbach, L.K., Bereiter, R., Mueller, E., Krebs, R., and Gaelli, R. 2008. Removal of oxide nanoparticles in a model wastewater treatment plant: influence of agglomeration and surfactants on clearing efficiency. Environmental Science and Technology 42(15): 5828-5833.

Sukhanova, A., Devy, M., Venteo, L., Kaplan, H., Artemyev, M., Oleinikov, V., Klinov, D., Pluot, M., Cohen, J.H.M., and Nabiev, I. 2004.Biocompatible fluorescent nanocrystals for immunolabeling of membrane proteins and cells. Analytical Biochemistry 324(1): 6067.

Sun, X., Sheng, Z., and Liu, Y. 2013. Effects of silver nanoparticles on microbial community structure in activated sludge. Science of the Total Environment 443: 828-835.

Theron, J., Cloete, T.E., and de Kwaadsteniet, M. 2010. Current molecular and emerging nanobiotechnology approaches for the detection of microbial pathogens. Critical Reviews in Microbiology 36(4): 318-339.

Tiraferri, A., Vecitis, C.D., and Elimelech, M. 2011. Covalent binding of singlewalled carbon nanotubes to polyamide membranes for antimicrobial surface properties. ACS Applied Materials and Interfaces 3(8): 2869-2877.

Tiwari D. K., Behari J., and Sen P. 2008.Application of Nanoparticles in Waste Water Treatment. World Applied Sciences Journal 3(3): 417433.

Vahabi, K., Mansoori, G. A.,andKarimi, S. 2011. Biosynthesis of silver 
nanoparticles by fungus Trichodermareesei (a route for largescale production of AgNPs).Insciences Journal 1: 65-79.

Vecitis, C.D., Zodrow, K.R., Kang, S., and Elimelech, M. 2010. Electronicstructure-dependent bacterial cytotoxicity of single-walled carbon nanotubes. ACS Nano 4(9): 54715479.

Vikesland, P.J., and Wigginton, K.R., 2010. Nanomaterial enabled biosensors for pathogen monitoring e a review. Environmental Science and Technology 44(10): 3656-3669.

Wang, Y., Xue, X., and Yang, H. 2014. Synthesis and antimicrobial activity of boron-doped titanianano-materials, Chinese Journal of Chemical Engineering 22(4): 474-479.

World Health Organization (W.H.O.) 2004.Meeting the MDG drinking water and sanitation target: A mid-term assessment of progress. Geneva: WHO

Wu, L. F., and Ritchie, S. M. C. 2008. Enhanced dechlorination oftrichloroethylene by membranesupported Pd-coated ironnanoparticles. Environmental Progress 27(2): 218224.

Wu, L., Shamsuzzoha, M., and Ritchie, S. M. C. 2005. Preparation ofcellulose acetate supported zero-valent iron nanoparticles forthe dechlorination of trichloroethylene in water. Journal of Nanoparticle Research 7(4-5): 469476.

Wu, Z.,Zhang, Y., Tao, T., Zhang T., and Fong, H. 2010.Silver nanoparticles on amidoxime fibers for photo-catalytic degradation of organic dyes in waste water.Applied Surface Science 257(3):1092-1097.

Xin, Z., Lu L. V., Bingcai, P., Weiming, Z., Shujuan, Z., and Quanxing Z. 2011. Polymer-supported nanocomposites for environmental application: A review, Chemical Engineering Journal 170( 2-3): 381-394.

Xiu, Z.M., Ma, J., and Alvarez, P.J. J. 2011.Differential effect of commonligands and molecular oxygen on antimicrobial activity ofsilver nanoparticles versus silver ions. Environmental Scienceand Technology 45(20): 9003-9008.

Yan, J.L., Estevez, M.C., Smith, J.E., Wang, K.M., He, X.X., Wang, L., and Tan, W.H. 2007.Dye-doped nanoparticles for bioanalysis. Nano Today 2(3): 4450.

Yang, Q., Liao, Y., and Mao, L. 2012. Kinetics of photocatalytic degradation of gaseous organic compounds on modified TiO2/AC composite photocatalyst, Chinese Journal of Chemical Engineering 20(3): 572-576.

Yang, W.R., Ratinac, K.R., Ringer, S.P., Thordarson, P., Gooding, J.J., and Braet, F. 2010. Carbon nanomaterials in biosensors: should you use nanotubes or graphene? AngewandteChemie-International Edition 49(12): 2114-2138.

Yang, Y., Zhang, C., and Hu, Z. 2013. Impact of metallic and metal oxide nanoparticles on wastewater treatment and anaerobic digestion. Environmental Science: Processes Impacts 15: 39- 48 .

Zhang, C., Liang, Z., and Hu, Z. 2014. Bacterial response to a continuous long-term exposure of silver nanoparticles at sub-ppm silver concentrations in a membrane bioreactor activated sludge system. Water Research 50: 350-358.

Zhang, K., Kemp, K. C., and Chandra, V. 2012. Homogeneous anchoring of $\mathrm{TiO}_{2}$ nanoparticles on graphene sheets for waste water treatment. Materials Letters 81: 127-130. 
Zheng X., Chen Y., and Wu R. 2011a. Long-term effects of titanium dioxide nanoparticles on nitrogen and phosphorus removal from wastewater and bacterial community shift in activated sludge, Environmental Science and Technology 45(17): 7284-7290.

Zheng X., Su Y., and Chen Y.2012.Acute and Chronic Responses of Activated Sludge Viability and Performance to Silica Nanoparticles. Environ. Sci. Technol., 46: 7182-7188. dx.doi.org/10.1021/es300777b, 50: 350-358.
Zheng, X., Wu, R., and Chen, Y. 2011b.Effects of $\mathrm{ZnO}$ nanoparticles on wastewater biological nitrogen and phosphorus removal. Environmental Science and Technology 45(7): 28262832.

Zodrow, K., Brunet, L., Mahendra, S., Li, D., Zhang, A., Li, Q.L., and Alvarez, P.J. J. 2009.Polysulfone ultrafiltration membranes impregnated with silver nanoparticles show improved biofouling resistance and virus removal. Water Research 43(3): 715723.

\section{How to cite this article:}

Mahmoud M. Berekaa. 2016. Nanotechnology in Wastewater Treatment; Influence of Nanomaterials on Microbial Systems. Int.J.Curr.Microbiol.App.Sci. 5(1): 713-726 hittp://dx.doi.org/10.20546/ijcmas.2016.501.072 